\title{
Chronicling School Principals' Experiences on School Management in the Context of COVID-19 Stringency
}

\author{
Bonginkosi Hardy Mutongoza ${ }^{1}$, Babawande Emmanuel Olawale ${ }^{{ }^{*}}$ \& Busiswa Mzilikazi ${ }^{1}$ \\ *Corresponding Author: bolawale@ufh.ac.za \\ 1. Faculty of Education, University of Fort Hare, Alice, South Africa \\ Received : 2021-06-15 \\ Revised : 2021-08-18 \\ Accepted : 2021-09-24 \\ $10.46303 /$ ressat.2021.35
}

\begin{abstract}
How to cite this paper: Mutongoza, B.H., Olawale, B.E. \& Mzilikazi, B. (2021). Chronicling School Principals' Experiences on School Management in the Context of COVID-19 Stringency. Research in Social Sciences and Technology, 6(3), 146-162. https://doi.org/10.46303/ressat.2021.35

This is an Open Access article distributed under the terms of the Creative Commons Attribution 4.0 International license (https://creativecommons.org/licenses/by/4.0/).
\end{abstract}

\begin{abstract}
The COVID-19 pandemic experience has brought to the forefront the importance of leadership as institutions across the world are now trying to emerge from hibernation and rebuild broken academic practices. As such, this study sought to examine school principals' experiences on school management in the context of COVID-19 stringency in four rural schools in the Eastern Cape Province of South Africa. Underpinned by a qualitative research approach, the study employed a case study design in which semi-structured interviews were used to collect data from four rural school principals who had been purposively sampled. Findings of the study revealed that in order to combat challenges associated with teaching and learning, school principals engaged among other things, in mobilization of resources, engendering a technological culture among teachers, ensuring effective delivery of content. We further ascertained that although hamstrung by resource inadequacies, school principals in rural schools promoted school safety by ensuring transparent and effective communication, striving for the provision of safe and adequate facilities, among other things. Finally, our study also revealed that rural school principals ensured clear and consistent communication with staff, provided psychosocial assistance to staff members, and adapted performance and workload expectations.
\end{abstract}

Keywords: online learning; quality education; COVID-19; school leadership; rural schools.

\section{Introduction and background}

In order to save lives and contain the transmission of the COVID-19 virus, many countries were locked down - this meant that along with other sectors, business activities closed, and most education institutions were closed (Gautam \& Gautam, 2020). Accordingly, the teaching and learning process of over 1.5 billion learners and students (about $72 \%$ of children and youth in 
Mutongoza, B.H., Olawale, B.E. \& Mzilikazi, B. Chronicling School Principals' Experiences on School Management in the Context of COVID-19 Stringency

education institutions), were affected as of May 2020 (UNESCO, 2020). In order to rescue teaching and learning during the COVID-19-induced disruptions, education institutions worldwide were forced to abruptly adopt online learning models (Muhuro \& Kang'ethe, 2021). The impact of this abrupt transformation was most acute in the developing world where institutions and communities were underprepared owing to the lack of infrastructure that is essential for online pedagogies and a lack of financing for this transformation (Dube, 2020; Mncube et al., 2021). According to UNESCO (2020), more than 13 million learners in schools, and over 1.1 million students in higher education institutions were inordinately affected by the COVID-19 pandemic. In fact, Mahaye (2020) contended that in Africa, South Africa ranks fourth in terms of numbers of learners affected by the COVID-19 pandemic. This therefore reveals that the COVID-19-insprired disruptions have indeed brought to the fore the need for effective education leadership, which is geared towards improving teaching and learning outcomes, especially in the developing world.

Without a doubt, COVID-19 is toppling the world as we know it, by ravaging economies, abruptly transforming societies, and drastically altering educational practices (Harris, 2020). The COVID-19 quickly became a supernova (Azorın, 2020) which created undeniable chaos (Hargreaves \& Fullan, 2020) that abruptly changed education systems globally. The onset of the COVID-19 pandemic dramatically refined learning to a remote, screen-based activity which limited the interaction between learners and teacher support (Harris \& Jones, 2020). In many ways, COVID-19 heightened a lot of important issues and revealed how inequity in education affects students and those in the society (Mncube et al., 2021). A prominent concern was the widening of inequalities in education as ochestrated by the emergency adoption of online learning. Rural institutions and schools lamented the lack of adequate resources in coparison with their more urban counterparts (Dube, 2020; Muhuro \& Kang'ethe, 2021). Crises oftentimes reveal the centrality of leadership in providing guidnce to avert dangers which threaten the continuity of organizations globally (Bundy et al., 2017). It is not uncommon for school leaders to receive an increased scrutiny during these challenging times because people expect leaders to assist, guide, comfort, and provide accurate information (Northouse, 2016).

The COVID-19 pandemic has posed adaptive challenges that have reminded all players that collective challenges are best-solved through cooperation and synergies (Fernandez \& Shaw, 2020; Williams et al., 2021). Leadership practitioners in academic circles are thus tasked with the effective response strategies to the COVID-19 crisis (Huber \& Helm, 2020; Mncube et al., 2021). Studies have shown that school leaders establish this by cultivating a democratic culture which promotes trust, accountability and collaboration (Kezar et al., 2018; Fernandez \& Shaw, 2020). The COVID-19 pandemic has deeply affected the functionality of education institutions and societies, as seen in the abrupt closures of schools and education instiutions. Teachers' previous 'control' over the learning environment and schedule have now been challenged by the new environment which relies heavily on learner autonomy (Huber \& Helm, 2020; Kalimullina et al, 2021). This study therefore sought to examine rural school principals' experiences on school management in the wake of COVID-19 in the Eastern Cape Province, South Africa. 
Mutongoza, B.H., Olawale, B.E. \& Mzilikazi, B. Chronicling School Principals' Experiences on School Management in the Context of COVID-19 Stringency

\section{Statement of the problem}

The COVID-19 pandemic has brought to the forefront inequalities which are extant in communities around the world (Czerniewicz et al., 2020; Therborn, 2020). The education sector has not been impervious to the menacing effects which continue to plummet prospects of quality education - particularly in poor and rural communities (Gunter et al., 2020; Hodges et al., 2020; Naidu, 2020). While the majority of developing countries around the world have been heavily reliant on traditional methods of classroom-based instruction methods which demand classroom presence in order to satisfy the goal of teaching, the 'new normal' has brought to the fore the need for alternative methods of instruction (Motala \& Menon, 2020; Roy, 2020; Williamson et al., 2020; Muhuro \& Kang'ethe, 2021). The centrality of leadership is thus brought to the fore by the need to rebuild broken academic practices in communities where online learning was inaccessible or indeed accessible to a limited extent (Chinembiri, 2020; Roy, 2020; Wright, 2020). This paper therefore sought to examine principals' experiences on school management amid the COVID-19 pandemic in the Eastern Cape Province, South Africa.

\section{Research Questions}

In order to examine school principals' experiences on school management amid the COVID-19 pandemic, this study was sought to answer the following questions:

- How have school principals in rural schools sustained teaching and learning during the COVID-19 pandemic?

- How have school principals in rural schools promoted safety in schools during the COVID-19 pandemic?

- How do school principals in rural schools engender a healthy operational environment for staff in their schools during the COVID-19 pandemic?

\section{Literature Review}

Although there had already been debates on the possibilities of imparting and sustaining education offline (Fajriyah \& Rodriguez, 2018), these debates have been made more urgent as education institutions explore the effectiveness of digital platforms as a strategy for curbing the challenges posed by the COVID-19 pandemic (Sinha \& Basu, 2020). Proponents of remote learning contend that remote teaching promotes asynchronous learning and provides learners with the freedom needed to learn at their own pace (Barr \& Miller, 2013; Fajriyah \& Rodriguez, 2018). This thus allows learners the access to course materials and practice their skills at any time, which is mostly possible through online courses (Sinha \& Basu, 2020). As such, the current COVID-19 situation demands teachers to be abreast with online technologies, and to be innovative in order to learning requirements (Gautam \& Gautam, 2020; Sinha \& Basu, 2020). However, studies revealed that schools in developing contexts faced significant challenges to transform to an online teaching and learning during the pandemic (Basilaia \& Kvavadze, 2020; Lee \& You, 2020). According to Plitnichenko (2020), although teachers and administrators work hard during the pandemic to keep learners on track, they continue to face challenges with regards to organization of work and time management. It is further contended that the shortage of gadgets, connectivity, computer illiteracy, poor adjustment of delivery methods to include learners with disabilities, data privacy, security, isolation, and social isolation, continue 
Mutongoza, B.H., Olawale, B.E. \& Mzilikazi, B. Chronicling School Principals' Experiences on School Management in the Context of COVID-19 Stringency

to impede the prospects of online learning (Brooks, et al., 2020; Lee \& You, 2020; Plitnichenko, 2020).

The COVID-19 pandemic has forcibly fast-tracked the transformed academic institutions into digital home-based institutions which rely heavily on virtual interaction, simulation, and collaboration (Thamarana, 2016; Gautam \& Gautam, 2020), the psychological impact of this mode of delivery must not be overlooked (Brooks, et al., 2020). Hence, educators, leadership and school management should be mindful that the protracted confinement of learners to home environments is capable of deterring physical and psychosocial well-being (Leite et al, 2020). The impact of the COVID-19 pandemic will potentially impact on school principals' view of their emergent profession's future prospects (Stone-Johnson \& Weiner, 2020). In fact, studies on school management reveal the multi-faceted nature of duties which principals are oftentimes expected to fulfil (Davis et al., 2005; Lunenburg, 2011; Mendels, 2012). Tobin (2014) thus argues that principal duties are ever-evolving and require constant upskilling in order to deliver effective leadership. According to Lunenburg (2010), this dynamism makes principals' daily duties inherently multifaceted, and the pressures huge. Principals are thus tasked with providing instructional leadership, oversight of the curriculum, refining the teaching programme, working to define the school's vision and mission, and fostering collaboration with their communities (Botha, 2004; Mestry, 2017). Principals are also expected to oversee management of their schools by managing the budget, maintaining infrastructure, and ensuring compliance with policies and acts (Mestry, 2017).

Thus, as principals lead in the wake of the COVID-19 pandemic, the standard of service has been expanded. As a result, school principals are attempting to attend to the vast inequalities and needs of their stakeholders in order to bolster the effectiveness of their work (StoneJohnson \& Weiner, 2020). To this end, Habegger (2008), argues that a positive school cultureis the bedrock of successful schools. Thus, principals should promote a sense of belonging, make efforts to create relationship between school, parents and various community members, and provide clear directions for both teachers and learners (Harris, 2020). Thus, for principals to promote posivite school culture during crises, Petersoni et al. (2018) argues that attempts should be made by the government and school leaders to help teachers in their instruction practices. This can be achieved by nurturing teachers' pedagogies which are aimed at affording learners the guidance and motivation required for active learning. In addition, educational administration programmes must provide opportunities for building potential leaders to learn and fulfil the array of daily governance tasks that confront presentday principals (Tobin, 2014).

\section{Theoretical framework}

Fred Fiedler's Contingency Trait Theory developed in the 1960s underpins this study. The basic premise of Contingency Theory is that there are several ways in which organisations can be led (Flinsch-Rodriguez, 2010). This means that the best way to lead can only be depends on the constraints (internal and external) in a given situation. Studies show that the effectiveness of leadership relies on three contingencies: (i) qualities of the leader (skills, traits, behaviours, etc.), (ii) the followers (maturity, behaviours, skills, etc.) and (iii) the given situation (goals, urgency, nature of work, etc.) (Pointer, 2006; Deckard, 2011; Nyenswah et al., 2016). The most effective leaders therefore morph their responses to challenges based on these contingencies (Flinsch- 
Mutongoza, B.H., Olawale, B.E. \& Mzilikazi, B. Chronicling School Principals' Experiences on School Management in the Context of COVID-19 Stringency

Rodriguez, 2010). According to Fiedler (1971), three dimensions determine the favourableness of the situation to a leadership approach: (i) relations between the leader and members, (ii) the degree of the task structure, and (iii) the position power of the leader. According to Fiedler (1971), when a leader is new and unaccepted, leader-member relations are low, while the same are better-placed when a leader is accepted and respected. Fiedler (1971) further explains that the degree of task structure is low in instances where tasks are not clearly defined, and high in instances where tasks are well-structured, and routines are predictable. In the same vein, the position power of the leader is often low in cases where less power is attributed to the leader, and high where positional power is attributed formally to a leader (Fiedler, 1971). This theory is suitable for the study given the current COVID-19 situation because it emphasizes the flexibility of school principals to evaluate situations and make decisions unique to situation at hand. Thus, applying contingency theory requires school principals to stay alert on their jobs and avoid over-reliance on rules, policies, and tradition as the only guide for their choices. Therefore, to improve school productivity, enhance academic performance and staff's morale in the wake of COVID-19 pandemic, principals must understand the importance of contingency theory and its positive implication at schools.

\section{Methodology}

\section{Research design}

Underpinned by a qualitative approach, the researchers adopted a multiple case study design for this study. The case study design allowed the researchers to a get a deeper insight into the selected cases for investigation (Creswell \& Creswell, 2018). According to Yin (2018), in a case study, 'the case' can either be a singular case or a collective of cases which are to be explored in-depth. As such, we employed a case study design in order to ascertain the managerial experiences of school principals at selected schools in Nkonkobe Municipality in the Eastern Cape Province, South Africa. The design allowed us to gain a comprehensive outlook of managing schools in the wake of the COVID-19 pandemic. This is in line with Yin (2018) who argues that the use of case study allows the researcher to establish mutual understanding amongst research participants.

\section{Study sample}

Four (4) school principals in Nkonkobe Municipality in the Eastern Cape Province of South Africa were purposively sampled. The judgement used of selecting participants was the length of service as principals in their respective schools, thus of the Participants we approached for the study, we ended up with 4 Participants who were willing to participate in the study whose length of experience as school principals ranged from nine years to thirteen years. This allowed us to get in-depth perspectives on the changes which have occurred in the leadership demands placed on principals in the wake of the COVID-19 pandemic as opposed to the outlook which we could have gathered from recently appointed principal. Table 1 below presents the general characteristics of the participants. 
Mutongoza, B.H., Olawale, B.E. \& Mzilikazi, B. Chronicling School Principals' Experiences on School Management in the Context of COVID-19 Stringency

Table 1. Characteristics of the study participants

\begin{tabular}{|l|c|c|c|}
\hline Participant & Age & Sex & Experience (years) \\
\hline Principal A & 53 & F & 13 \\
\hline Principal B & 49 & M & 10 \\
\hline Principal C & 58 & M & 9 \\
\hline Principal D & 54 & F & 11 \\
\hline
\end{tabular}

\section{Data collection}

Data were collected using semi-structured online interviews whose duration was about $20-30$ minutes. The questions in the interviews were generated by the researchers based on the research questions. The interviews were conducted in English, although the participants had been encouraged to respond in any language they could best express their views in. Semistructured interviews allowed us to keep the interviews focussed, while at the same time ensuring that we could further probe and seek clarity on aspects which may have required clarification. Semi-structured interviews were deemed appropriate because we sought to understand the perspectives and experiences of our interviewees.

\section{Data analysis}

Once the data were collected, we began the process of transcribing the data. In order to reduce mistakes and enhance trustworthiness, we firstly checked the accuracy of the transcribed recordings with two colleagues who served as critical readers, and then subsequently employed member-checks with the participants. Afterwards, we employed thematic analysis of the data collected because thematic analysis can be used to analyse almost any kind of qualitative data regardless of the size of datasets. Thematic analysis also allowed us to capture complex, messy, and contradictory experiences of the school principals. We were guided by Creswell and Creswell (2018) who argue that thematic analysis enables the identification of patterns and relationships to meaningfully answer research questions in a study. The first step was to familiarize ourselves with the data individually, and then we compared our perspectives, digging deeper where there were contradictions and concerns. After this, we developed initial codes for the data, then tested these themes for referential adequacy. We went on to generate final themes under which the data were reported. Data trustworthiness was ascertained through the triangulation of cases. 
Mutongoza, B.H., Olawale, B.E. \& Mzilikazi, B. Chronicling School Principals' Experiences on School Management in the Context of COVID-19 Stringency

\section{Ethical considerations}

In order to uphold research ethics, we observed the following ethical considerations in this study:

- Participants were informed of their rights to confidentiality, anonymity, and privacy before the collection of data; and

- We provided participants with the information about research aims, process and how their data were to be used prior to seeking consent.

- We informed the participants that they were free to withdraw from the research at any point with no costs, and if they withdrew, their data would not be used in the study

\section{Results and Discussion}

We sought to examine principals' experiences on school management in the context of COVID19 stringency in the Eastern Cape Province of South Africa. In accordance with the research questions, our results are organised as follows:

- Sustaining teaching and learning in rural schools

- Promoting safety in rural schools

- Engendering healthy operational environment for staff in rural schools

\section{Sustaining teaching and learning in rural schools}

To examine principals' experiences on school management in the context of COVID-19 stringency, participants were asked: "How have you as a school principal in a rural school sustained teaching and learning during the COVID-19 pandemic?" Research findings revealed that although schools have moved from the traditional method of contact-based learning to a more blended form of learning which involves remote learning, the lack of access to online resources still poses a challenge for rural schools. Thus, school principals engaged in mobilization of resources, engendering a technological culture among teachers, ensuring effective delivery of content, and the management of learners' varying subject needs. Principals revealed that the pandemic had forced their schools to adopt online learning despite the challenges faced by schools in rural communities. A case in point can be drawn from a principal who revealed:

During the lockdown, we started using it (online learning) because we had to continue with teaching and learning regardless of the situation. After the intense part of the lockdown, we decided to keep this mode of learning...it has been greatly beneficial to us. So now we say maybe it's another added resource - online learning. It is not the conventional type of online learning which is experienced in other parts of the world, but we are doing the best that we can with the limited resources which we have. We make use of social media and messaging platforms - these are not tailored for learning, but it is what has been helpful. For our practical subjects, we have instead resolved to use online videos and then when students attend classes on the rotational basis which the government has designed, we revise these and make touch-ups. (Principal A) 
Mutongoza, B.H., Olawale, B.E. \& Mzilikazi, B. Chronicling School Principals' Experiences on School Management in the Context of COVID-19 Stringency

This view was corroborated by another participant who noted that owing to the disruptions induced by the COVID-19 pandemic, the principal now carries a burden to mobilize resources to ensure that learning continued despite the closures of schools. The participant opined,

[...] we have had to source for funds, and in some instances, we have had to redirect funds in order to continue with the teaching programme. We quickly realized that if we do not change with the times, we would fall apart, and we would be the ones to pay for the loss of teaching and learning time...the school has managed to source additional support from the SGB which has gone a long way in assisting our blended learning model. (Principal B)

In addition, Principal $\mathrm{D}$ also supported the above response with regards to the shift in teaching and learning, however, the participant lamented on the lack of access to online resources. For example, the principal stated that:

We are rural schools...there are limited resources, no data to access online materials. Even when you try to download and send learner materials or ask them to join an online session, there are several complaints...teachers too - we have had to train them to be flexible enough to adopt a technological culture. With the younger staff complement, it is easy, but the older ones need extra motivation. As the principal, it is my duty to make sure that everyone is on board with this strategy in order for it to be successful. (Principal D)

Similarly, Principal $C$ acknowledged the shift from traditional learning to blended learning, but also highlighted the shortcoming of an emergency remote teaching, the participant added that:

[...] we have moved forcefully into teaching and learning online, but it becomes impossible for some learners who offer science specific subjects such as physical sciences, chemistry etc. This is because the subjects have a practical component and not just theories that can be learnt remotely. In addition, it becomes a bit difficult for teachers, especially the older ones who lack technological skills to effectively deliver teaching and learning contents concurrently with virtual classes in a blended learning approach. So, to ensure that there is effective delivery of content, we have designed a model of oversight. We designed a system of oversight where we constantly work to adapt to the unique needs and resources of our students and staff.

From these findings, one could conclude that although school principals and staffs accepted the transition to blended learning which was because of the outbreak of COVID-19 pandemic, there remain some underlying challenges in some rural schools such as the lack of technological culture among staffs, access to online resources, and the type of subjects being taught may compromise the delivery of online teaching. This finding substantiates the view of Plitnichenko (2020) who posited that although teachers and administrators are working hard to keep learners on track in the face of the COVID-19 pandemic, the extant challenges which confront rural institutions threaten the success of this new mode of learning. This buttresses the view that most education institutions in the developing world are not ready for the adoption of new technologies (Mncube et al., 2019; Waters \& Hensley, 2020). Our study further revealed that the pandemic has abruptly changed the face of teaching and learning and has indeed forced school principals to come up with creative solutions to the COVID-19 stringency. Although this 
Mutongoza, B.H., Olawale, B.E. \& Mzilikazi, B. Chronicling School Principals' Experiences on School Management in the Context of COVID-19 Stringency

transformation was abrupt, Mahaye (2020) reminds practitioners that the new movement towards an online teaching and learning models is a unique opportunity for learners to access course materials and practice their skills. This however requires teachers to be familiar with technology, as well as being innovative in order to employ technology in their teaching and learning methods to fulfil educational purposes (Sinha \& Basu, 2020; Waters \& Hensley, 2020). As demonstrated by the Contingency Trait Theory which emphasizes the flexibility of leaders to evaluate situations and make decisions unique to situation at hand (Fiedler, 1971), principals' experiences of managing schools in the wake of the pandemic has revealed that principals have had to employ novel strategies which ensure that their schools deliver the academic mandate which they have been tasked with. As institutions adopt online learning, and indeed other forms of blended learning which have ensured that learning can continue away from the traditional school setting, demands arise to consider varying needs which may hinder the home environment from being an effective alternative.

\section{Promoting safety in rural schools}

To ascertain the school management experiences of principals in the wake of the COVID-19 pandemic, participants were further asked, "How have you as a school principal in a rural school promoted safety during the COVID-19 pandemic?" Our findings revealed that although hamstrung by resource inadequacies, school principals in rural schools promoted school safety by ensuring transparent and effective communication in cases of risk, enforcing government COVID-19 protocols, striving for the provision of safe and adequate facilities for teaching when contact learning resumed, and developing disaster preparedness plans which are aligned to the pandemic. The principals revealed that they had become creative, even in instances where government regulations appeared to be unclear. A case in point can be drawn from a participant who argued:

Before reopening, the school was fumigated by school support teams. We marked out all our facilities to ensure that we adhere to the social distancing guidelines. In addition, we also have sanitizers almost everywhere in the school for learners and staff to use. The wearing of masks is also compulsory for anyone within the school vicinity. However, we received guidelines from the Department of Education, which are not clear, but as school leaders, we had to discuss this with staff members in order to restructure some rules to suit out staffs and learners...there is nothing much to keep people safe other than facemask and hand sanitizers. (Principal D)

In addition to striving to provide safe and adequate facilities for learning in line with government regulations of social distance and sanitizing, Principal A revealed that the COVID19 pandemic has forced principals to rethink the effectiveness of their communication strategies to improve the safety prospects of staff and students, even in the absence of temporary facilities for isolation. The principal revealed the centrality of clear communication strategies:

We do not have an isolation facility of any sorts...so as a result, if any of the staff or learners are showing any of the symptoms, or has a high temperature, we do not allow them access to the school - they will have to go back home. We also do contact tracing and communicate with the individual's contacts informing them when someone tests 
Mutongoza, B.H., Olawale, B.E. \& Mzilikazi, B. Chronicling School Principals' Experiences on School Management in the Context of COVID-19 Stringency

positive. However, we try our best to check up on them and we do communicate frequently via the school WhatsApp group. Also, as the school principal, I move from one staffroom to classes to check the wellbeing of both learners and staff. We also dedicate the early hours of every morning to a brief staff meeting to discuss issues that can enhance staff productivity. (Principal A)

Contingency emergency response planning has also come to the fore as Principal B revealed the creation of relations with a nearby clinic to help promote the health and safety of learners and staff in the wake of COVID-19 pandemic. The principal attested:

Some of our learners and staff do not come from close to the school, they have to take transport to come to school. Our catchment area goes beyond our immediate vicinity, we cater for even some communities which are far from us, this increases the risk of transmission for both students and staff. Some of these regulations are enacted with a limited scope which is removed from the situation obtaining in rural areas. To salvage safety from the ravaging pandemic, we test and isolate learners and staff, we have also stopped outsiders - whether parents or anyone else, from accessing the school. Anyone who shows symptoms, we have established a relationship with the clinic close by, we immediately call for assistance...they have been very helpful. (Principal B)

On the contrary, Principal $C$ revealed that the school was unable to guarantee the safety of learners and staff owing to the lack of resources. The principal could not do anything beyond the bare minimum of enforcing government regulations:

We do not really have enough to ensure the safety of our staff and learners. When we opened, we had to force matters...we did not have enough resources, no proper guidelines but we had to open anyways. We are just enforcing the mask and sanitizer; beyond that we really do not have much. For us to do anything more will require money but unfortunately our coffers are dry - the pandemic was a huge blow financially for us...even enforcing social distance is practically impossible, we just do not have sufficient space to allow for that. (Principal C)

Research findings revealed that school safety continues to be significantly affected by the lack of resources and the provision of unclear directives, thereby making the role of school principals strenuous, school principals in rural schools still endeavour to enhance school safety by ensuring transparent and effective communication in cases of risk, enforcing government COVID-19 protocols, striving for the provision of safe and adequate facilities for teaching, and developing disaster preparedness plans which are aligned to the pandemic. This can find rooting in earlier studies which contended that school principals were increasingly being tasked with multiple roles as their leadership would always be required on an evolving basis (Asmawi et al., 2013; Tobin, 2014). In addition, the Contingency Trait Theory also argues that leadership is in itself fluid, and not static, thus there can never be one best way to lead (Flinsch-Rodriguez, 2010), rather, the environment in which a leader operates dictates the specific traits required to grapple with challenges (Pointer, 2006; Deckard, 2011; Nyenswah et al., 2016). The centrality of effective management can therefore be noted in the various efforts by principals as they strove to rebuild broken academic practices in communities which were hamstrung by the extant inequalities in education (Chinembiri, 2020; Roy, 2020; Wright, 2020). It thus becomes 
Mutongoza, B.H., Olawale, B.E. \& Mzilikazi, B. Chronicling School Principals' Experiences on School Management in the Context of COVID-19 Stringency

clearer that rural school principals are faced with considerably more challenges than those confronting their colleagues in more urban settings, and the COVID-19 pandemic has made the role of the school principal in rural South Africa more strenous.

\section{Engendering healthy operational environment in rural schools}

To examine principals' experiences on school management in the context of COVID-19 stringency, participants were also asked: "How do you as a school principal in a rural school engender a healthy operational environment for staff during the COVID-19 pandemic?" Our findings in this regard revealed that the rural school principals had an awareness of the psychosocial stresses which staff members were grappling with in the wake of the COVID-19 pandemic, and to alleviate these stresses, principals ensured clear and consistent communication with staff, adapted work expectations, provided psychosocial assistance to staff members, and adapted performance and workload expectations. In emphasizing the adaptation of performance expectations and workload management, Principal B lamented:

The enormity of the workload is drowning our staff. They have very little time to cover a lot of work. Even though the curriculum was revised, there is a lot to do. Most teachers are experiencing health issues related to workload...the management of the workload is not really going as expected. It's not easy but we are trying by setting clear expectation and achievable work plan.

Principal D further revealed that the uncertainties regarding changes in the curriculum had necessitated need for extra motivation for staff. Principal $D$ ascertained:

Although the curriculum has been resized, there is a lot of uncertainty. There is talk that part of the curriculum that was removed this year will be added to next year curriculum. As a result, we sacrifice our time on Saturdays to cover as much work as we can. Thus, we encourage teachers to come on weekend with added incentives as a way of motivating to resist comparison to what the school used to be before COVID-19...we found it necessary to provide extra motivation for our staff in these trying times.

The principals also highlighted the psychosocial assistance which is increasingly becoming critical in the wake of the COVID-19 pandemic. A case in point can be drawn from Principal C who revealed:

COVID-19 has heavily impacted the wellbeing of almost everyone in society. We are juggling several aspects - deaths, isolation, stigmatization, fear, and many more. As a principal, I have the duty to make sure that there is a semblance of psychosocial wellness among staff. This is because psychosocial wellness has a direct impact on productivity in the workplace. As a result, when a staff member is facing challenges that impact on mental health, we refer them for counselling and also give them time off work. This is how we are promoting a healthy working environment. (Principal C)

This was corroborated by another principal who further underscored the importance of clear and consistent communication models as a way of improving workplace environment. The principal argued: 
Mutongoza, B.H., Olawale, B.E. \& Mzilikazi, B. Chronicling School Principals' Experiences on School Management in the Context of COVID-19 Stringency

One of the crucial aspects that has made it possible for us to rebuild workplace wellness has been the use of consistent and clear communication. We have made it clear to staff that it is okay not to be okay. We made it clear that we are in this together and we also communicate coping strategies which make it possible for us all to survive this pandemic which is now taking its toll. (Principal A)

The findings of this study revealed that although there exist constraints to staff wellbeing during pandemic, principals promote healthy working environment through the establishment of clear and consistent communication patterns, adapting expectations, motivating workers by use of incentives, assisting staff with workload management, and providing psychosocial assistance. This therefore aides the quest by principals to promote the development of human relations, and collaborative action to guarantee school development and effectiveness. This concurs with the views of Stone-Johnson and Weiner (2020) who opine that the impact of the COVID-19 pandemic will potentially impact on school principals' view of their emergent profession's future prospects. As a result, it becomes a 'new normal' for principals to attend to the needs and inequalities which buffet the stakeholders in education owing to the pandemic (StoneJohnson \& Weiner, 2020). Thus, principals have a duty to promote a sense of belonging, make efforts to create relationship between school, learners, parents, and various community members, towards the provision of clear directions for both teachers and learners (Habegger, 2008). This corroborates the views of Botha (2004) and Mestry (2017) who stated that principal's position in governing schools in post-apartheid South Africa requires a balance between management and instructional leadership. This is because school leadership focuses on working to identify the school's vision and mission, and improving instructional programme of the school, while management includes factors such as budget supervision, maintaining infrastructure, and ensuring compliance with policies and acts (Botha, 2004; Mestry, 2017). As such, the school principals in rural schools have an important role in promoting healthy working environments for staff in their schools.

\section{Conclusion and Recommendations}

The abrupt shift of schools to remote online learning at the onset of the COVID-19 pandemic disrupted teaching and learning across the world and has revealed some deep-seated inequalities which exist in South African education. We set out to investigate examine rural school principals' experiences on school management in the wake of the COVID-19 pandemic. Our study revealed that in order to ameliorate challenges associated with teaching and learning, school principals engaged in mobilization of resources, engendering a technological culture among teachers, ensuring effective delivery of content, and the management of learners' varying subject needs. We further ascertained that although hamstrung by resource inadequacies, school principals in rural schools promoted school safety by ensuring transparent and effective communication in cases of risk, enforcing government COVID-19 protocols, striving for the provision of safe and adequate facilities for teaching when contact learning resumed, and developing disaster preparedness plans which are aligned to the pandemic. Finally, our study also revealed that the rural school principals had an awareness of the psychosocial stresses which staff members were grappling with in the wake of the COVID-19 pandemic, and to alleviate these stresses, principals ensured clear and consistent 
Mutongoza, B.H., Olawale, B.E. \& Mzilikazi, B. Chronicling School Principals' Experiences on School Management in the Context of COVID-19 Stringency

communication with staff, provided psychosocial assistance to staff members, and adapted performance and workload expectations.

Based on these findings, we recommend that there should be continuous training for school leaders to equip them with skills to handle their ever-evolving leadership roles. Furthermore, while the principals appear to be offering psychosocial assistance to their staff, we recommend the provision of qualified personnel by the Department of Basic Education to assist with mental wellness of both students and staff. We further recommend that the Department of Basic Education must work to provide financial assistance to help rural schools with resources which improve their operational capacities. Finally, this study was focused on rural school principals' experiences on school management in the wake of the COVID-19 pandemic, and thus it only relied on school management from the perspective and experiences of school principals. As such, we recommend that further studies be conducted to ascertain the effectiveness of these strategies employed by rural school principals, this could include the views of learners, teachers, School Governing Bodies, among others.

\section{References}

Asmawi, A., Zakaria, S. \& Chin Wei, C., (2013). Understanding transformational leadership and R\&D culture in Malaysian universities. Innovation, 15(3), 287-304. https://doi.org/10.5172/impp.2013.15.3.287

Azorın, C., (2020). Beyond COVID-19 supernova: Is another education coming? Journal of Professional Capital and Community, 1-10. https://doi.org/10.1108/JPCC-05-2020$\underline{0019}$

Barr, B., \& Miller, S., (2013). Higher Education: The online teaching and learning experience. Retrieved from https://files.eric.ed.gov/fulltext/ED543912.pdf

Basilaia, G., \& Kvavadze, D., (2020). Transition to online education in schools during a SARSCoV-2 Coronavirus (COVID-19) pandemic in Georgia. Pedagogical Research, 5(4), 1-9. https://doi.org/10.29333/pr/7937

Botha, R. J., (2004). Excellence in leadership: demands on the professional school principal. South African Journal of Education, 24(3), 239-243.

Brooks, S., Webster, R., Smith, L., Woodland, L., Wessely, S., Greenberg, N., \& Rubin, G., (2020). The psychological impact of quarantine and how to reduce it: rapid review of the evidence. Rapid Review, 912-920. https://doi.org/10.1016/S0140-6736(20)30460$\underline{8}$

Bundy, J., Pfarrer, M. D., Short, C. E., \& Coombs, W. T., (2017). Crises and crisis management: Integration, interpretation, and research development. Journal of Management, 43(6), 1661-1692. https://doi.org/10.1177/0149206316680030

Chinembiri, T., (2020). Mobile data pricing policy brief. Research ICT Africa, June. Retrieved from https://researchictafrica.net/wp/wp-content/uploads/2020/06/TapiwaChinembiri-Mobile-Data-Pricing-Policy-Brief2-2020-FINAL.pdf. 
Mutongoza, B.H., Olawale, B.E. \& Mzilikazi, B. Chronicling School Principals' Experiences on School Management in the Context of COVID-19 Stringency

Creswell, J., \& Cresswell, J., (2018). Research design qualitative, quantitative, and mixed methods approaches. Los Angeles, United States of America: Sage Publications.

Czerniewicz, L., Agherdien, N., Badenhorst, J., Belluigi, D., Chambers, T., Chili, M., ... \& Wissing, G. (2020). A wake-up call: Equity, inequality and Covid-19 emergency remote teaching and learning. Postdigital Science and Education, 2(3), 946-967. https://doi.org/10.1007/s42438-020-00187-4

Davis, S., Darling-Hammond, L., LaPointe, M., \& Meyerson, D., (2005). School leadership study: Developing successful principals. Stanford Educational Leadership Institute. Retrieved from https://edpolicy.stanford.edu/sites/default/files/publications/school-leadershipstudy-developing-successful-principals.pdf.

Deckard, G. J., (2011). Contingency theories of leadership. In Borkowski N. (Ed.), Organizational behavior in health care (2nd ed.), 191-208. Jones and Bartlett Publishers.

Dube, B. (2020). Rural online learning in the context of Covid-19 in South Africa: Evoking an inclusive education approach. Multidisciplinary Journal of Educational Research, 135157. https://doi.org/10.17583/remie.2020.5607

Fajriyah, R., \& Rodriguez, P., (2018). Implementing the computer-supported collaborative learning and teaching in a statistics class for the engineering students. Journal of Physics: Conference Series, 1028, https://doi.org/10.1088/1742-6596/1028/1/012233

Fernandez, A., \& Shaw, G., (2020). Academic leadership in a time of Crisis: The Corona Virus and COVID-19. Journal of Leadership Studies, 14(1), 39-45.

https://doi.org/10.1002/jls.21684

Fiedler, F. E. (1971). Validation and extension of the contingency model of leadership effectiveness: A review of empirical findings. Psychological bulletin, 76(2), 128. https://doi.org/10.1037/h0031454

Flinsch-Rodriguez, P., (2010). Contingency Management Theory. Retrieved from https://www.business.com/articles/contingency-management-theory/

Gautam, D., \& Gautam, P., (2020). Transition to Online Higher Education during COVID-19 Pandemic: Turmoil and Way Forward to Developing Country of South Asia- Nepal. [Preprint version], 1-26. https://doi.org/10.21203/rs.3.rs-59206/v1

Gunter, A., Raghuram, P., Breines, M. R., \& Prinsloo, P., (2020). Distance education as sociomaterial assemblage: Place, distribution, and aggregation. Population, Space and Place, 26, e2023. https://doi.org/10.1002/psp.2320

Habegger, S. (2008). The Principal's Role in Successful Schools: Creating a Positive School Culture. Principal, 42-46.

https://www.naesp.org/sites/default/files/resources/1/Principal/2008/S-0 p42.pdf

Hargreaves, A., \& Fullan, M., (2020). Professional Capital after the Pandemic: Revisiting and Revising Classic Understandings of Teachers' Work. Journal of Professional Capital and Community. https://doi.org/10.1108/JPCC-06-2020-0039 
Mutongoza, B.H., Olawale, B.E. \& Mzilikazi, B. Chronicling School Principals' Experiences on School Management in the Context of COVID-19 Stringency

Harris, A. (2020). COVID-19 - School leadership in crisis? Journal of Professional Capital and Community, 5 (3/4), 321-326. https://doi.org/10.1108/JPCC-06-2020-0045

Harris, A., \& Jones, M., (2020). COVID 19 - school leadership in disruptive times. Journal of School Leadership \& Management, 40(4), 243-247.

https://doi.org/10.1080/13632434.2020.1811479

Hodges, C.; Moore, S.; Lockee, B.; Trust, T. \& Bond, A., (2020). The difference between emergency remote teaching and online learning. Educause Review, 27 March.

Retrieved from https://er.educause.edu/articles/2020/3/thedifference-betweenemergency-remote-teaching-and-online-learning

Huber, S. G., \& Helm, C., (2020). COVID-19 and schooling: evaluation, assessment and accountability in times of crises-reacting quickly to explore key issues for policy, practice and research with the school barometer. Educational Assessment, Evaluation and Accountability, 32(2), 237-270. https://doi.org/10.1007/s11092-020-09322-y

Kalimullina, O., Tarman, B. \& Stepanova, I. (2021). Education in the Context of Digitalization and Culture: Evolution of the Teacher's Role, Pre-pandemic Overview. Journal of Ethnic and Cultural Studies, 8(1), 226-238. DOI: http://dx.doi.org/10.29333/ejecs/629

Kezar, A., Fries-Britt, S., Kurban, E., McGuire, D., \&Wheaton, M. M., (2018). Speaking truth and acting with integrity: Confronting challenges of campus racial climate. Washington: American Council on Education.

Leavy, P., (2017). Research Design: Quantitative, Qualitative, Mixed Methods, Arts-Based, and Community-Based Participatory Research Approaches. New York, NY: Guilford Publications

Lee, M., \& You, M., (2020). Psychological and behavioral responses in South Korea during the early stage of Coronavirus disease 2019 (COVID-19). International Journal of Environmental Research and Public Health, 17, 1-14. https://doi.org/10.3390/ijerph17092977

Leite, H., Hodgkinson, I. R., \& Gruber, T. (2020). New development: 'Healing at a distance'telemedicine and COVID-19. Public Money \& Management, 40(6), 483-485. https://doi.org/10.1080/09540962.2020.1748855

Lunenburg, F. C., (2011). Leadership versus management: A key distinction - at least in theory. International Journal of Management, Business, and Administration, 14(1), 1-9.

Mahaye, N., (2020). The Impact of COVID-19 Pandemic on Education: Navigating Forward the Pedagogy of Blended Learning. Retrieved from https://www.researchgate.net/publication/340899662 The Impact of COVID19 Pandemic on South African Education Navigating Forward the Pedagogy of Blended Learning

Mendels, P., (2012). The effective principal: 5 pivotal practices that shape instructional leadership. Journal of Staff Development, 33(1), 1-4. 
Mutongoza, B.H., Olawale, B.E. \& Mzilikazi, B. Chronicling School Principals' Experiences on School Management in the Context of COVID-19 Stringency

Mestry, R., (2017). Empowering principals to lead and manage public schools effectively in the 21st century. South African Journal of Education, 37(1), 1-11. https://doi.org/10.15700/saje.v37n1a1334

Mncube, V., Mutongoza, B. H., \& Olawale, E., (2021). Managing higher education institutions in the context of COVID-19 stringency: Experiences of stakeholders at a rural South African university. Perspectives in Education, 39(1), 390-409. https://doi.org/10.18820/2519593X/pie.v39.i1.24

Mncube, V., Olawale, E., and Hendricks, W., (2019). Exploring teachers' readiness for eLearning: On par with the Fourth Industrial Revolution? International Journal of Knowledge, Innovation and Enterprise, 7(2), 5-20

Motala, S. \& Menon, K., (2020). In search of the 'new normal': Reflections on teaching and learning during COVID-19 in a South African university. Southern African Review of Education, 26(1), 80-99.

Muhuro, P., \& Kang'ethe, S. M. (2021). Prospects and pitfalls associated with implementing blended learning in rural-based higher education institutions in Southern Africa.

Perspectives in Education, 39(1), 427-441.

https://doi.org/10.18820/2519593X/pie.v39.i1.26

Naidu, E., (2020). Concerned academics call for halt to online learning. University World News, (23 April 2020), Retrieved from https://www.universityworldnews.com/post.php?story=20200423064438186

Northouse, P. G., (2016). Leadership: Theory and practice (7th ed.). Thousand Oaks, CA: Sage.

Nyenswah, T., Engineer, C. Y., \& Peters, D. H. (2016). Leadership in times of crisis: the example of Ebola virus disease in Liberia. Health Systems \& Reform, 2(3), 194-207. https://doi.org/10.1080/23288604.2016.1222793

Petersoni, A., Dumontii, H., Lafuente, M., \& Lawiii, N., (2018). Understanding innovative pedagogies: Key themes to analyse new approaches to teaching and learning. (O. E. Papers, Ed.) Paris: OECD Publishing.

Plitnichenko, L. (2020). Ten Challenges of E-Learning during Covid-19. Retrieved from https://jellyfish.tech/10-challenges-of-e-learning-during-covid-19/

Pointer, D. D., (2006). A framework for thinking and acting. In S. Shortell, \& A. D. Kaluzney (Eds.), Health care management: organization design and behavior. Clifton Park, NY: Cengage Learning.

Roy, A., (2020). The pandemic is a portal: An online teach-in with Arundhati Roy [Youtube.com]. https://www.youtube.com/watch?v=QmQLTnK4QTA

Sinha, A., \& Basu, D., (2020). Educational Landscape during and after COVID-19 Pendamic: Strategies and Adaptation to encourage quality teaching and learning. Agricultural Extension in South Asia, 1(1), 1-9. 
Mutongoza, B.H., Olawale, B.E. \& Mzilikazi, B. Chronicling School Principals' Experiences on School Management in the Context of COVID-19 Stringency

Stone-Johnson, C., \& Weiner, J., (2020). Principal professionalism in the time of COVID-19. Journal of Professional Capital and Community, 5(3/4), 367-374 https://doi.org/10.1108/JPCC-05-2020-0020

Thamarana, S. (2016). Role of E-learning and Virtual Learning Environment in English language learning. Retrieved from https://www.researchgate.net/publication/305913807 Role of Elearning and Virtual Learning Environment in English language learning?channel= doi\&linkld=57a5ba4208aefe6167b500f9\&showFulltext=true

Therborn, G., (2020). How the dimensions of human inequality affect who and what we are. The Conversation, 8 July 2020. Retrieved from https://theconversation.com/howthedimensions-of-human-inequality-affect-who-andwhat-we-are-137296

Tobin, J., (2014). Management and Leadership Issues for School Building Leaders. NCPEA International Journal of Educational Leadership Preparation, 9(1), 1-14.

UNESCO, (2020). COVID-19 educational disruption and response. Retrieved from https://en.unesco.org/covid19/educationresponse/

Waters, S., \& Hensley, M. (2020). Measuring rural P-12 teachers' attitudes, perceptions and utilizations of social media. Research in Social Sciences and Technology, 5(3), 25-54. https://doi.org/10.46303/ressat.05.03.2

Williams, T; Mclntosh, R., \& Russell, W. (2021). Equity in distance education during COVID-19. Research in Social Sciences and Technology, 6(1), 1-24. https://doi.org/10.46303/ressat.2021.1

Williamson, B., Eynon, R. \& Potter, J., (2020). Pandemic politics, pedagogies and practices: Digital technologies and distance education during the coronavirus emergency. Learning, Media and Technology, 45(2), 107-114. https://doi.org/10.1080/17439884.2020.1761641

Wright, L., (2020). How pandemics wreak havoc-And open minds. The New Yorker, 13 July 2020. Retrieved from https://www. newyorker.com/magazine/2020/07/20/howpandemics-wreak-havoc-and-open-minds

Yin, R. (2018). Case study research and applications: Design and methods. Los Angeles: Sage Publications 